\title{
SCC with activated recycled concrete fines
}

\author{
Vitali Naruts ${ }^{1}$, Oksana Larsen ${ }^{1, *}$, and Anton Bakhrakh ${ }^{1}$ \\ ${ }^{1}$ Moscow State University of Civil Engineering, Yaroslavskoe shosse, 26, Moscow, 129337, Russia
}

\begin{abstract}
The main application of concrete waste is its use as a coarse aggregate in concretes. Recycled concrete fines can be also used in concrete mixtures as fine aggregates or fillers. The paper describes an efficient activation method of recycled concrete fines to obtain technological, economical and ecological benefits. The idea is to combine mechanical and chemical methods of activation. According to various experiments the addition of superplasticizer into the mill speeds up grinding process. The present investigation shows that adding $0.5 \%$ by mass of recycled concrete fines allows obtaining higher specific area at the same processing time. Use of the prepared filler in SCC increases compressive strength more than $10 \%$ in compare with SCC containing limestone powder and mechanically activated recycled concrete fines.
\end{abstract}

\section{Introduction}

Mechano-chemical activation is an effective method of obtaining low water demand binders and active fillers for concretes. The substance of method is in adding dry superplasticizer into the mill droning grinding cement or other disperse materials [1].

Mechanical activation implies growth of specific area of grinded material. Higher specific area for cement and other active materials provides higher chemical reactivity [2]. Concrete based on mechanically activated cement with specific area more then $0.4 \mathrm{~m}^{2} / \mathrm{kg}$ has higher compressive strength on 7, 14 and 28 day of hardening [3]. The main problem of superfine cements and fillers is high water demand, so that obtaining mortars with good flowability and high compressive strength becomes impossible $[4,5]$.

Chemical activation of cement and fillers with superplasticizers promotes the formation of polymer shell on the surface of grains [6]. Combination of chemical and mechanical activation provides faster grinding due the Rehbinder effect [7]. Mechanochemically activated cements and fillers have low water demand, application of such materials promotes reduction of water to cement ratio [8]. Use of mechanochemically activated fillers is appropriate in self-compacting concretes (SCC) due to their composition concept. Necessary components of SCC are various fillers, added in order to enlarge the amount of disperse paste, reduce segregation and optimise the granulometry of the mortar [9]. Selfcompacting mortar is a mortar which can be used in reinforced constructions without any mechanical efforts [10]. SCC has very high flowability and at the same time cohesiveness

*Corresponding author: larsen.oksana@mail.ru 
enough to exceed bleeding or segregation. Self-compacting concrete provides such benefits as reduction of construction time and labour cost, refusal of vibration, reduction of noise pollution, high compressive strength and dense structure [11, 12, 13]. Application of mechanochemically activated concrete grinding fines will not only improve rheological properties of SCC mix, but also increase compressive strength of hardened concrete.

\section{Experimental section}

During experiments 3 compositions of SCC with different fillers such as limestone powder, mechanically activated concrete grinding fines and mechano-chemically activated recycled concrete fines were designed.

\subsection{Materials}

\subsubsection{Cement}

Cement used in the study was Ordinary Portland Cement type I 42.5N Mordovcement with content of $\mathrm{C}_{3} \mathrm{~A}<8 \%$ and $\mathrm{C}_{3} \mathrm{~S}>55 \%$.

Table 1. Quality parameters of cement.

\begin{tabular}{|c|c|c|c|c|c|c|}
\hline \multicolumn{7}{|c|}{ Mechanical properties } \\
\hline \multirow{2}{*}{$\begin{array}{c}\text { Water for } \\
\text { standard } \\
\text { consistence, \% }\end{array}$} & \multirow{2}{*}{$\begin{array}{l}\text { Time of setting, } \\
\text { min }\end{array}$} & \multicolumn{4}{|c|}{ Compressive strength, $\mathrm{MPa}$} & \multirow{2}{*}{$\begin{array}{c}\text { Expansion, } \\
\mathrm{mm}\end{array}$} \\
\hline & & \multicolumn{2}{|r|}{ 2-day } & \multicolumn{2}{|r|}{ 28-day } & \\
\hline $26.0-28.0$ & 160 & & 23.0 & & 51.7 & 0 \\
\hline \multicolumn{7}{|c|}{ Chemical composition of cement } \\
\hline $\mathrm{SO}_{3}$ & Admixtures & & oss on ignition & & luble residue & $\mathrm{Cl}^{-}$ \\
\hline 2.92 & 4.34 & & 1.27 & & 4.17 & 0.006 \\
\hline \multicolumn{7}{|c|}{ Mineralogical composition of cement } \\
\hline $\mathrm{C}_{3} \mathrm{~S}$ & $\mathrm{C}_{2} \mathrm{~S}$ & $\mathrm{C}_{3} \mathrm{~A}$ & & & $\mathrm{CaO} / \mathrm{SiO}_{2}$ & $\mathrm{MgO}$ \\
\hline 59.97 & 16.55 & 6.58 & & & 3.01 & 1.12 \\
\hline
\end{tabular}

\subsubsection{Concrete grinding fines}

Concrete grinding fines used this investigation were produced by the Satori company and has grain size $0-5 \mathrm{~mm}$.

Table 2. Quality parameters of concrete grinding fines.

\begin{tabular}{|c|c|c|c|}
\hline Finneness modulus & Class & True density, $\mathrm{g} / \mathrm{cm}^{3}$ & Inorganic impurities, $\%$ \\
\hline 3.0 & II & 2.64 & 0.2 \\
\hline
\end{tabular}

Grading of concrete grinding fines shows that its granulometry is similar to ordinary quartz sand used as a fine aggregate in concretes.

Table 2. Grading of concrete grinding fines.

\begin{tabular}{|c|c|c|c|c|c|c|c|}
\hline Sieve size, mm & 5.0 & 2.5 & 1.25 & 0,63 & 0,315 & 0,16 & Bottom \\
\hline Residue on sieve, \% & \multirow{2}{*}{5.9} & 25.1 & 15.5 & 19.1 & 21.5 & 13.3 & 5.5 \\
\cline { 1 - 7 } & & 25.1 & 40.6 & 59.7 & 81.2 & 94.5 & 100 \\
\hline
\end{tabular}


Table 4. Chemical composition of concrete grinding fines, $\%$.

\begin{tabular}{|c|c|c|c|c|c|c|c|c|c|c|c|c|}
\hline $\mathrm{SiO}_{2}$ & $\mathrm{CaO}_{2}$ & $\mathrm{Al}_{2} \mathrm{O}_{3}$ & $\mathrm{Fe}_{2} \mathrm{O}_{3}$ & $\mathrm{MgO}$ & $\mathrm{K}_{2} \mathrm{O}$ & $\mathrm{SO}_{3}$ & $\mathrm{Na}_{2} \mathrm{O}$ & $\mathrm{P}_{2} \mathrm{O}_{5}$ & $\mathrm{TiO}_{2}$ & $\mathrm{SrO}$ & $\mathrm{SiO}_{2}$ & $\mathrm{CaO}_{2}$ \\
\hline 68.08 & 18.45 & 5.41 & 2.3 & 1.66 & 1.43 & 0.726 & 1.03 & 0.128 & 0.238 & 0.385 & 68.08 & 18.45 \\
\hline
\end{tabular}

\subsubsection{Superplasticizers}

Superplasticizer Melflux 5581F was used during mechano-chemical activation of concrete grinding fines. Melflux 5581F is based on polycarboxylates. Recommended dosage of superplasticizer by producer is $0.05-0.5 \%$ from the mass of cement.

Superplasticizer used in SCC composition was Sika ViscoCrete S 600 SP.

\subsubsection{Aggregates}

Crushed granite with a maximum size of $20 \mathrm{~mm}$ and true density of $2700 \mathrm{~kg} / \mathrm{m}^{3}$ was used as coarse aggregate. The amount of flake form coarse aggregate was $20 \%$. Quartz sand with true density of $2640 \mathrm{~kg} / \mathrm{m}^{3}$ and fineness modulus of 1.8 was used as fine aggregate in this investigation. Base filler was limestone powder MP-1 produced by the «Gurovo-Beton» company.

\subsection{Experimental part}

Experimental part was performed in two stages. The first one was mechanical and mechanochemical activation of concrete grinding fines. Designing composition of SCC with 3 types of fillers, preparing of mixes and compressive strength tests of hardened concrete was the second one.

\subsubsection{Activation of concrete grinding fines}

Concrete grinding fines were activated in a laboratory vibration mill. Value of specific area of the material grinded together with superplasticizer is $14.3 \%$ percent higher than of material activated mechanically at the same time of grinding. Results of specific area determination prove the effect of superplasticizer on strength of the crushed material.

Table 5. Specific area of grinded filler.

\begin{tabular}{|c|c|c|c|c|c|c|c|}
\hline \multirow{2}{*}{$\begin{array}{c}\text { Dosage of } \\
\text { Melflux } \\
5581 \mathrm{~F}(\%)\end{array}$} & \multicolumn{7}{|c|}{ Grinding time, $\min /$ Specific area $\mathrm{cm}^{2} / \mathrm{g}$} \\
\hline & 30 & 45 & 60 & 75 & 90 & 120 & 150 \\
\hline 0 & 2903 & 3315 & 3599 & 3789 & 3825 & 3923 & 3978 \\
\hline 0.5 & 3115 & 3705 & 3989 & 4186 & 4268 & 4473 & 4546 \\
\hline
\end{tabular}




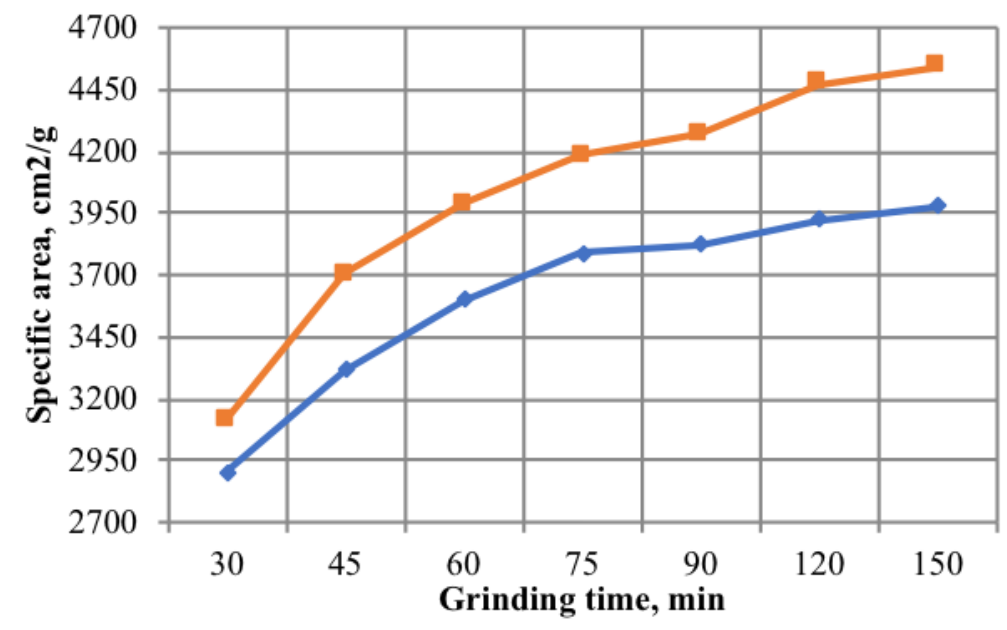

Fig 1. Specific area of grinded filler.

\subsubsection{Determination of effect on SCC compressive strength}

Three compositions of SCC with different types of fillers were designed. Proportions of raw materials were constant in all compositions. Compositions were designed in accordance with recommended proportions of components for SCC in order to obtain proper flowability.

Table 6. SCC compositions.

\begin{tabular}{|c|c|c|c|c|c|c|c|}
\hline \multirow{2}{*}{ Fixture } & Filler type & Cem. & Filler & Granite & Sand & $\begin{array}{c}\text { Sika } \\
\text { ViscoCrete } \\
\text { S 600 SP }\end{array}$ & Water \\
\cline { 3 - 8 } & MP-1 & 400 & 200 & 810 & 810 & 2.4 & 180 \\
\hline 1 & $\begin{array}{c}\text { Grinded } \\
\text { concrete }\end{array}$ & 400 & 200 & 810 & 810 & 2.4 & 180 \\
\hline 2 & $\begin{array}{c}\text { Grinded } \\
\text { concrete + } \\
\text { Melflux } \\
5581 \mathrm{~F}\end{array}$ & 400 & 200 & 810 & 810 & 2.4 & 180 \\
\hline
\end{tabular}

All three mixes were prepared and their reologic properties were invstigated. Composition mix №3 demonstrated slump flow test results of $772 \mathrm{~mm}$ which is highest result comparing with compositions № 1 and №2.

\section{Results}

Cubic samples 100x100x100 mm were made from prepared mixes in order to determine compressive strength on 3, 7 and 28 days of hardening. Samples with mechanochemically activated filler showed highest test results. Composition №3 with compressive strength on the 3 day was $43.6 \mathrm{MPa}, 7$-day and 28-day compressive strength was of $52.1 \mathrm{MPa}$ and 67.2 $\mathrm{MPa}$ respectively. 
Table 7. Compressive strength of SCC.

\begin{tabular}{|c|c|c|c|}
\hline \multirow{2}{*}{ Mix } & \multicolumn{3}{|c|}{ Compressive strength, MPa } \\
\cline { 2 - 4 } & 3-day & 7-day & 28-day \\
\hline 1 & 41.2 & 48.9 & 60.4 \\
\hline 2 & 39.5 & 46.5 & 58.1 \\
\hline 3 & 43.6 & 52.1 & 67.2 \\
\hline
\end{tabular}

\section{Conclusions}

According to the results of the present research effective use of concrete grinding fines in SCC requires mechanochemical activation by grinding with polycarboxylate superplasticizer.

Introduction of Melflux 5581F superplasticizer into the mill in amount of $0.5 \%$ from the mass of grinded fillers speeds up the dispersion process. Filler milled in the presence of superplasticizer has $14.3 \%$ larger specific area comparing to single milled filler at the same activation time.

Use of mechanochemically activated concrete grinding fines in SCC as a filler provides better rheological properties of mortar and higher compressive strength of hardened concrete at all periods of curing.

\section{References}

1. V. Kumar, A. Singh, P. Hemanth Journal of Asian Ceramic Societies, 3 (2015)

2. G. Mucsi, A. Racz, V. Madai, Powder technology, 235 (2013)

3. I. Mehdipour, K. H. Khayat, Cement and Concrete Composites, 78 (2017)

4. M. Karamloo, M. Mazloom, G. Payganeh, Construction and Building Materials 123 (2016)

5. G. Peiwei, D. Min Cem. and concr. Res., 31 (2001)

6. A. Allahverdi, A. Maleki, M. Mahinroosta, J. of build. Eng., 18 (2018)

7. D. Eugene, A. Shichkin, Colloids and surfaces A: Physomechanical and Engeneering Aspects 149 (2018)

8. J. Rissanen, K. Ohenoja, P. Kinnunen, M. Romagnoli, M. Llikakainen, Constr. and Build. Mat., 180 (2014)

9. H. Okamura, M. Ouchi, J. of Adv. Concrete Techn., 1 (2003)

10. H.J.H. Brouwers, H.J. Radix, First International Symposium on Design, Performance and Use of Self-Consolidating Concrete SCC 2005 - China, (26 - 28 May 2005)

11. K. Sobolev, Z. Lin, Y. Cao, H. Sun, W. Jason Weiss, Cem. and Concr. Comp., 71 (2016)

12. D. Pedro, J. de Brito, L. Evangelista, Cem. and Concr. Comp, 93 (2018)

13. Á. Salesa, J.A. Pérez-Benedicto, D. Colorado-Aranguren, P. L. LópezJulián, D.Olivares, M. Omrane, S. Kenai, E. Kadri, A. Aït-Mokhtar, J. of Cl. Prod.,141 (2017) 